\title{
Intimate partner violence against pregnant women: the environment according to Levine's nursing theory*
}

\author{
Violência perpetrada por parceiro íntimo à gestante: \\ o ambiente à luz da teoria de Levine \\ Violencia a la embarazada perpetrada por compañero íntimo: \\ el entorno a la luz de la teoría de Levine
}

Selma Villas Boas Teixeira', Maria Aparecida Vasconcelos Moura², Leila Rangel da Silva', Ana Beatriz Azevedo Queiroz², Kleyde Ventura de Souza ${ }^{3}$, Leônidas Albuquerque Netto ${ }^{2}$

\footnotetext{
* Extracted from the thesis "Violência de gênero contra a mulher grávida perpetrada pelo parceiro íntimo: análise à luz da Teoria de Levine," Escola de Enfermagem Anna Nery, Universidade Federal do Rio de Janeiro, 2013.

${ }^{1}$ Universidade Federal do Estado do Rio de Janeiro, Escola de Enfermagem Alfredo Pinto, Rio de Janeiro, RJ, Brazil.

${ }^{2}$ Universidade Federal do Rio de Janeiro, Escola de Enfermagem Anna Nery, Rio de Janeiro, RJ, Brazil.

${ }^{3}$ Universidade Federal de Minas Gerais, Escola de Enfermagem, Belo Horizonte, MG, Brazil.
}

\section{ABSTRACT}

Objective: Analyzing the elements that compose the environment of pregnant women who have experienced intimate partner violence in the light of Levine's Nursing Theory. Method: A qualitative, descriptive study conducted from September to January 2012, with nine pregnant women in a Municipal Health Center in Rio de Janeiro. The interviews were semi-structured and individual. The theoretical framework was based on Levine's Nursing Theory. Results: Thematic analysis evidenced the elements that composed the external environment, such as violence perpetrated by intimate partners before and during pregnancy, violence in childhood and adolescence, alcohol consumption and drug use by the partner, unemployment, low education and economic dependency, which affected health and posed risks to the pregnancy. Conclusion: Violence perpetrated by an intimate partner was the main external factor that influenced the internal environment with repercussions on health. This theory represents a tool in nursing care which will aid in detecting cases and the fight against violence.

\section{DESCRIPTORS}

Violence Against Women; Pregnancy; Spouse Abuse; Maternal-Child Nursing; Women's Health. 


\section{INTRODUCTION}

Violence against women perpetrated by an intimate partner (IPV) is a complex multifaceted phenomenon that has been recognized in recent decades as a serious public health and social problem throughout the world ${ }^{(1-2)}$. It can be characterized as any action or omission based on gender causing death, injury, physical, sexual or psychological suffering and moral or financial damage ${ }^{(3)}$.

The configurations of violence against women is comprised of physical violence, which may include any conduct that offends the integrity or physical health of women; psychological violence, including threats, humiliation, isolation, and persecution, among others; moral violence characterized by slander, libel and defamation; patrimonial violence characterized by theft, retention of or damage to material possessions, resources and documents; and sexual violence, unwanted sex, sexual acts without consent and the impediment of contraceptive use ${ }^{(3)}$.

For women during a pregnancy period, IPV has even more serious proportions because their pregnancy may have been a consequence of violence itself, or the case for its occurrence, with implications that can be harmful to the mother's and newborn's health ${ }^{(2)}$. The implications of such violence are associated with a delay in starting prenatal care, premature labor, bleeding, miscarriage, and depression, among others, with possible fatal outcomes to mother and fetus ${ }^{(2,4-5)}$.

International ${ }^{(5-7)}$ and national ${ }^{(8-11)}$ studies indicate a high prevalence of IPV during pregnancy, which can be severe and recurrent in a continuous pattern ${ }^{(10-11)}$. Elements for its occurrence can be identified as: economic dependency, low education, unplanned pregnancy, previous experience of violence in childhood or adolescence and abuse of legal and/ or illegal drugs ${ }^{(1-2,5)}$. Notably, such violence is inserted in the field of gender violence, since it is based on a historical and socio-cultural construct that assigns asymmetric relations between men and women, implying unequal power relations based on a dominant and submissive relationship ${ }^{(12)}$.

Therefore, the implementation of prevention and response strategies to IPV such as female empowerment and the expansion of opportunities for participation in economic activities have been gaining relevance, thus becoming a prioritized issue on political agendas in the health care field ${ }^{(1)}$.

However, addressing IPV in the health care sector is generally considered a challenging task, as the predominant complaint-conduct clinical practice is limited, given the magnitude and repercussions on maternal and perinatal health. This fact requires theoretical and methodological frameworks that support the practices of health professionals and in particular those of nurses working in prenatal care, both from the standpoint of treatment/assistance as well as the investigation and production of knowledge ${ }^{(13)}$.

With respect to nurses, it is necessary that they recognize IPV as a multifaceted phenomenon that may bring consequences to maternal health, by understanding/getting to know their environment through the care and bonds of trust acquired by their constant presence in health facilities ${ }^{(14)}$.

This research was focused on IPV during pregnancy by using a nursing theory (Levine's Nursing Conservation Model Theory) that applies the environmental concept as one of its pillars. This model enables the maintenance or recovery of physical, mental, social and spiritual individual well-being. The choice for this theory was aimed at supporting nurses in providing individualized and comprehensive care, considering the individual as a holistic and dynamic being. This means that it (the being) constantly interacts with its environment and it depends on their relationship with other people, family and the social environment in order to maintain health ${ }^{(15)}$.

The environment is understood as internal and external, both complete the entirety of the individual's health The external environment is considered the social context in which the individual lives and participates. Three characteristics are used to define the aspects of environment: the operating environment, related to environmental components that can inconspicuously affect individuals, such as micro-organisms, pollutants and radiation; the perceptual environment consists of information that is registered by sensory organs; and conceptual environment, influenced by culture, ideas, cognition and language ${ }^{(15)}$.

In this context, the internal environment represents the physiological aspects of the individual, constantly influenced by the external environment, with positive or negative impacts on health. The latter should not be considered a static condition, since the individual may be fully healthy and suddenly come across a pathological process arising from the external environment ${ }^{(15)}$. Therefore, in this study the physiological aspects are understood as the biopsychosocial and spiritual balance corresponding to pregnant women's health; while the pathological to the negative impact caused by IPV to their health.

For that, nurses need to know and understand the external and internal environments of pregnant women, to support their actions and provide care. The care should be directed at meeting their individual needs, valuing them as an active and participative being ${ }^{(15)}$. This means that prenatal care must reach beyond the biological and reproductive aspects, paying attention to the subjectivity, given that some health problems may be caused by a hostile external environment.

This study is justified by the importance of discussing the issue of IPV during pregnancy in light of a Nursing theoretical framework, and understanding the elements that relate to and underlie this phenomenon, considering its magnitude and negative repercussions on the health of pregnant women.

Given the above, the objective was defined as analyzing the elements that compose the environment of pregnant women who have experienced IPV in the light of Levine's Nursing Theory.

\section{METHOD}

A qualitative, descriptive and exploratory research. The setting was the outpatient Gynecology and Obstetrics clinic 
of a Municipal Health Center that attends to normal risk pregnant women, located in the south of Rio de Janeiro city (RJ), Brazil.

Participant selection took place between the months of September 2011 and January 2012. During this period, 75 pregnant women were attended to in prenatal nursing consultations by the main researcher, which had questions about IPV in pregnancy in the medical history questionnaire (anamnesis). Of this total, nine pregnant women met the inclusion criteria: experiencing IPV during pregnancy, being older than 18 and having prenatal care consultations at the study site. Participation was voluntary, by signing of the Informed Consent Form.

The data collection technique was by semi-structured and individual interviews. The guidelines were developed by the research group, and had open and closed questions aimed at collecting socioeconomic and obstetric characteristics and IPV during pregnancy, thereby allowing for the extraction of external and internal environment elements of the participants.

Interviews with the participants were previously scheduled for before or after pre-natal consultations, subject to their availability, and were conducted at the clinic in private rooms, without the presence of companions. Interviews lasted about 50 minutes and were recorded in MP3 (format) with prior approval of pregnant women for later transcription. In order to guarantee the anonymity of women, identification codes were adopted by using the letter $\mathrm{D}$ followed by ordinal numbers in ascending order (D1...D9) according to the interview order.

For data analysis, the analysis of thematic content ${ }^{(16)}$ was conducted according to the following steps: pre-analysis, material exploration, treatment of the results, inference and interpretation. First transcription and organization of the interviews were done, enabling exploration of the material and the encoding process, resulting in 89 thematic units. Of this total, 67 units concerning the external and internal environment of pregnant women were grouped, which are related to the main themes - violence in the marital relationship before and during pregnancy, the family environment relationship, health repercussions of the violence which constituted the thematic category of this manuscript named The external and internal environments of pregnant women who experience IPV.

The study was approved by the Ethics Committee of the Municipal Health and the Civil Defense of Rio de Janeiro (SMSDC-RJ) number CAAE 0058.0.226.314-11. Ethical aspects were respected, according to Resolution No. 466/12 of the National Health Council - Ministry of Health.

\section{RESULTS}

With respect to socioeconomic data, participants were in the age group of 21-35 years and resided in the south of Rio de Janeiro; five declared themselves as being white; six reported not completing primary school. Family income was between one and three minimum wages, corresponding to $\mathrm{R} \$ 607.88$ (current value at the time of this study). As for marital status, five were single. The others were married or were in stable unions. The relationship duration for single women with partners ranged from between three and five years, and from three to fifteen years for those in stable unions or were married. With respect to obstetric history, seven women were multiparous and no pregnancy was planned. All pregnant women had prenatal care started in the second trimester of pregnancy, and six reported the occurrence of at least one episode of abortion.

The results showed that of the nine respondents, six reported having experienced physical, psychological and/or sexual violence in childhood and adolescence, perpetrated by their father, siblings or step-parents; they also had witnessed aggression against their mothers, associated with alcohol abuse. Among the reports, two were selected and are presented below:

\section{My stepfather reached his hand up my private parts. I must've been about six years old (D2); There have always been fights in my house (...) my brothers were alcoholics, my father was also. At times, apart from mine, I witnessed aggres- sion against my mother (D4).}

The interaction of study participants with their intimate partners was marked by daily violence, since the beginning of the couple's relationship. The results showed that before pregnancy all participants experienced at least two forms of violence: psychological and moral. In addition to these types of aggression, eight of the nine women reported physical violence and three participants mentioned sexual violence. Thus, the aggressions and conflicts were already part of the couple's relationship, as shown in the following speeches:
No one could come to my house. I could not get close to the window. He hides and I'm afraid (...) (D3).
At first, we had discussions, that was all. But then
he assaulted me to hurt me, (...) He punched me
many times. There have always been conflicts (D4).

He never had a permanent job (...) I do not see his money. I support the house and the children (D5).
He wanted to have sex every day (...). One day I did not want to and he hit me (D6).

He always argued with me, calling me a bitch (D9).

When taking into account IPV situations during pregnancy, at least three forms of violence have been identified in all reports: moral, psychological and physical. The women's statements show the use of rude words, the way and manner of speaking that occurred during the discussions are presented in the following reports:

He once told me that my voice was grossing him out (...) He says things like that, that hurt (D2).

He offends me and swears at me (...) (D3).

He follows me every day (...) I'm scared (D5). 
He fights with me, verbally assaults me, threatens me (D9).

Regarding physical violence, the reports were damning: He pushes me and hits me (...) (D1).

If he feels like assaulting me, he will, he doesn't respect the pregnancy (D4).

In another statement, the participant reported physical violence in addition to the psychological violence:

He threatened to kill me when he learned about the pregnancy and told me that pregnant women get hit on the face and legs! And then he slapped me in the face (D1).

Some report having retaliated to the aggression:

He hits me, but I also do some damage to him (D6).

The following is the report of a pregnant woman who demonstrated overlap of other forms of violence, notably physical violence, followed by sexual violence:

After an argument, he hit me in the belly, which was already big, because he wanted to have sex and I did not. (...) He took me by force (D1).

With regard to sexual violence, the following speech serves as an illustration:

Even though I am pregnant, he wants it [sex] all the time (...) (D3).

For one of the participants, physical violence and sexual violence started with the current pregnancy:

He beat me and wanted to have sex all the time, but violent sex (...) (D9).

However, for six participants, the physical violence decreased, with an intensification of psychological violence, moral violence and sexual violence, with altered patterns in this period:

Now that I'm pregnant he isn't bitting me as much, but he verbally assaults me(...) I am obliged to open my legs for him every day (D3).

I think the physical aggression decreased, but be verbally assaults me and threatens me (D5).

Patrimonial violence was revealed by three pregnant women, according to the following speeches:

He lives with me (...) he does not work (...)(D1).

He disappeared with all my documents (...) he doesn't pay for anything (D3).

I am the one who buys everything in my house (...) he does not help (D5).

Increasing episodes of violence were also identified when partners consumed alcoholic beverages and/or illicit drugs:

He smokes marijuana and drinks; and when he drinks, he also bits me (D1).

When he drinks, everything is an excuse for violence (D9).
Another situation that emerged from the testimony of two participants was partner infidelity.

I've heard that he cheated on me with a neighbor

(...) (D1).

I know he has several women (...) (D2).

The stories show that the various forms of IPV related to the external environment predominated in the everyday lives of these women before pregnancy, which were perpetuated during pregnancy. The feelings of sadness, fear and insecurity were reported in all statements, and one of them sums it up this finding:

I am very depressed because I'm afraid (...) I'm always crying (D2).

Another set of testimonials demonstrates different effects of IPV during pregnancy, relating to the internal environment, such as changes in body weight, elevated blood pressure, dyspareunia, headache, sleep disorders and physical pain:

I'm never bungry. (...), my body aches, my head and my belly burt (D1).

I try to maintain my weight, but I'm very sad and I start eating everything that is in front of me. That's why I gained weight (D3).

I have a lot of headaches (...), I can't sleep (D5).

Ifeel a lot of pain during intercourse (...) (D6).

I think my [blood] pressure has changed because of this life I'm living (D8).

There is so much violence that I've lost weight during pregnancy. I'm weak! (D9).

\section{DISCUSSION}

Socioeconomic characteristics of the respondents were similar to those of the female population in IPV situation found in other studies ${ }^{(17-18)}$. The comparable variables are related to the greater number of single women, with white skin, mostly in their reproductive age, with low education levels, with a low paying job, putting them in unfavorable economic and social levels. Regarding obstetric history, other studies $^{(14,19)}$ with pregnant women in situations of violence indicate that most of them are multiparous women with previous abortion experiences and unplanned pregnancies who start prenatal care in the second trimester of pregnancy.

Research results have shown that some participants experienced physical, psychological and sexual violence since childhood or adolescence, which continued until the current relationship, with the latter being perpetrated by an intimate partner. For others, violence was configured as a situation of a marital relationship since the beginning of the relationship with the current partner, proving that the everyday external environment of the participants was characterized as violent and hostile.

For pregnant women who have experienced violence within the family environment during childhood and adolescence, mainly through negligence and sexual violence, the 
aggressions had been part of their everyday life since an early age. Therefore, some women have been living in a violent family atmosphere, highlighting a society model rooted in inequalities between genders in which the strongest prevails over the weakest ${ }^{(12)}$. This situation enhances the negative impact on mental health through low self-esteem that, in adulthood, will be reflected in the way they deal with their personal problems and the ability to meet their challenges, thus establishing a strong tendency to repeat violence in their relationships or with their own children, either accepting or perpetrating the violence, a circumstance which may represent an important risk factor and its continuity in the future $\mathrm{e}^{(20-21)}$.

In addition to having witnessed the assault that fathers and stepfathers commit against their mothers, the respondents found that alcohol consumption was associated with violence in the home. Alcohol use among one or more members of a family can affect all members in a negative way, leading to conflicts, as the user becomes aggressive, creating conditions for arguments and offenses that can end in physical and sexual aggression ${ }^{(2,21)}$.

Revisiting Levine theory in relation to the aspects of the perceived environment, all situations that human being experience in their external world, it captures and introjects, leading to lived experience for their future life ${ }^{(15)}$. Therefore, pregnant women who experienced violence in childhood and adolescence, either directly or witnessing the marital relationship between the parents, it may have registered in their sensory system that negative day-to-day experience that possibly impacted their lives as a model to be followed.

Regarding the conceptual environment ${ }^{(15)}$, considering the ability of human beings to live and experience emotion, as well as value systems and ways of life and the relationship with each other, the repeating pattern of experienced violence during their lives may have been the reason why the respondents accepted it and did not confront the IPV during their pregnancy.

In this way, IPV toward pregnant women permeates the families and culminates in relationships with their partners, finding it anchored in gender inequalities. The latter is responsible for creating the natural perspective that women should be submissive to men. However, to defend themselves, some women also beat their partners. Therefore, one has to think that not all are submissive, and that not all men are dominant; so violent marital relationships should be considered under a relational perspective in which each holds power segments, though unevenly, in which each developed their own strategies of domination or submission ${ }^{(2,12)}$.

The theme of violence against women has rekindled discussions about risk factors that favor the episodes of aggression committed by an intimate partner as being relevant to issues involving gender relations. However, studies confirm that the age group, economic dependence, level of education, use of legal and/or illegal drugs by a woman and her intimate partner are elements that can contribute to the phenomenon ${ }^{(6-7,21)}$. It is noteworthy that in this study there was no report of drug use by participants.
In this context, the external environment in which the women lived until their pregnancy was expressed as a violent social and family life, acting as a background to all the environmental information they have received throughout their lives. We emphasize that the various stimuli and reported actions within the operating environment, both perceived and conceived by the individual, get stored as historical elements of their experiences ${ }^{(15)}$. Thus, the external factors that were recorded by these women throughout their lives have been part of their reality, being recognized as true and common situations to their existence, suggesting how they experience and face violence.

The results also showed that for some respondents, assaults were perpetuated during pregnancy with the same intensity and frequency. For others, there was an increase or decrease in the standard of IPV during this period. This suggests that even in pregnancy, they were not spared from assaults.

Reports from some pregnant women showed that physical abuse decreased during pregnancy. However, other forms of violence (sexual, moral and psychological) were identified. Studies corroborate these results in pointing out that the standard of IPV during pregnancy can be changed in the form, frequency and severity, particularly where violence existed before pregnancy ${ }^{(7,10-11,14)}$.

Another interviewee stated that aggressive episodes were triggered due to the rejection of pregnancy by the partner. This is a reality in women's lives that relates to abusive partners ${ }^{(9)}$. Studies ${ }^{(22-23)}$ show that women who experience various forms of IPV before and/or during pregnancy have a greater chance of performing unsafe abortions. This practice poses a risk to the woman's life, and the opportunity to compromise their mental health ${ }^{(2)}$.

However, some pregnant women said they had experienced sexual violence before pregnancy, with it being necessary to consider that the pregnancy may have been the result of a violent act perpetrated by the partner ${ }^{(23)}$. It should be noted that there are risks to sexual and reproductive health and denial of sexual and reproductive rights that are subject to women in IPV situations ${ }^{(6,14)}$, such as the pregnant women of this study.

The partner's infidelity, also reported in this study, can be configured as more of an aggression against women, for the fact that finding this out at the time of pregnancy can weaken their self-esteem. This masculine behavior is often accepted as relevant to male sexuality ${ }^{(2)}$. It is noteworthy that although some respondents have stated that this male attitude caused conflicts between them, the relationship was maintained.

It is valid to point out that the participants were immersed in the cycle of violence, regardless of whether or not they were cohabiting with their partners, since all the aggressions did not have a single episode. Instead, they were cyclical and continuous. Therefore, this situation should be considered that violence is perpetrated not only against women, as it can result in possible negative consequences to the fetus and neonate ${ }^{(4,14)}$. Moreover, it is considered that aggression perceived by the body, which hurt, injure, and often bleed, transcend the 
physical marks and also affect the mental health of pregnant women, making it a challenge to maintain the biopsychosocial and spiritual balance in a hostile environment in order to maintain and preserve its entirety.

In this sense, all the elements that made up the external environment of pregnant women, such as IPV before and during pregnancy and the presence of violence in childhood and adolescence, alcohol consumption and drug use by the partner, unemployment, low education and the economic dependence of women influenced the internal environment of the participants. The events described by them of chronic pain, gastric disorders, high blood pressure, dyspareunia, sleep disorders and dietary patterns; in addition to sadness, fear and insecurity, revealed a negative impact on their physical, mental and sexual health, with risks to pregnancy, thus becoming a pathological process. These findings corroborate other studies ${ }^{(4-5)}$. The impairment of mental health can lead them to start prenatal visits after the first quarter $^{(1)}$, as evidenced in this investigation. Moreover, it can favor non-attendance to prenatal consultations and the use of legal and/or illegal drugs, among others ${ }^{(4)}$.

It is therefore necessary that the actions of nurses are guided to recognize the external environment of pregnant women, considering the socio-economic, family and cultural contexts involved in the care process. It should be noted that antenatal care is a privileged moment to discuss and clarify issues that are unique to each woman on an individual basis, through open and unprejudiced listening.

However, the training of nurses and health professionals in detecting cases of IPV during pregnancy is important, considering that respectfully asked questions can be shared based on interaction and dialogue that go beyond the physical examination, history and application of laboratory tests. It should be recognized that IPV is a phenomenon that affects the health and integrity of pregnant women, and should be perceived as an ethical violation of human rights.

\section{CONCLUSION}

The results have indicated that IPV before and during pregnancy was considered the main element of external environments influencing internal environments, negatively impacting the health of pregnant women. In addition, other elements that carried over into their daily lives can directly influence morbidity, as well as maternal and perinatal mortality. These implications persist even with evidence that is not consistent with current scientific and technological advances in the health sector for maternal and child health.

It is stressed that this study, in light of Levine's Nursing Theory, could contribute as a tool to professional nursing practice, especially in pre-natal care, as it enables implementing individualized and comprehensive care and takes into account aspects of the external environment. Therefore, it must be based in acceptance and support, representing one more strategy to detect cases of IPV during pregnancy in order to help women preserve their health and to leave the cycle of violence, thereby favoring the confrontation of the phenomenon.

Finally, the findings point to the need for further research with the use of Levine's Nursing Theory, in face of the scarcity of publications at a national and international level with respect to this theoretical framework and its applicability in the health of women.

\section{RESUMO}

Objetivo: Analisar os elementos que compõem o ambiente das gestantes que vivenciaram a violência perpetrada por parceiro íntimo à luz da Teoria de Levine. Método: Estudo qualitativo, descritivo, realizado de setembro a janeiro de 2012, com nove gestantes em um Centro Municipal de Saúde do Rio de Janeiro. As entrevistas foram individuais e semiestruturadas. O referencial teórico utilizado foi a Teoria de Levine. Resultados: A análise temática evidenciou os elementos que compuseram o ambiente externo, como a violência perpetrada por parceiro íntimo antes e na gestação, violência na infância e adolescência, consumo de álcool e drogas pelo parceiro, desemprego, baixa escolaridade e dependência econômica, os quais repercutiram na saúde, com riscos à gravidez. Conclusão: A violência perpetrada por parceiro íntimo foi o principal elemento externo que influenciou o ambiente interno, com repercussões à saúde. A Teoria representa uma ferramenta na assistência de enfermagem que favorecerá na detecção dos casos e no enfrentamento da violência.

\section{DESCRITORES}

Violência contra a Mulher; Gravidez; Maus-Tratos Conjugais; Enfermagem Materno-Infantil; Saúde da Mulher.

\section{RESUMEN}

Objetivo: Analizar los elementos que componen el ambiente de las gestantes que sufrieron violencia perpetrada por compañero íntimo a la luz de la Teoría de Levine. Método: Estudio cualitativo, descriptivo, llevado a cabo de septiembre a enero de 2012 , con nueve gestantes de un Centro Municipal de Salud de Río de Janeiro. Las entrevistas fueron individuales y semiestructuradas. El marco de referencia teórico fue la Teoría de Levine. Resultados: El análisis temático evidenció los elementos que compusieron el entorno exterior, como la violencia perpetrada por compañero íntimo antes y durante el embarazo, violencia en la infancia y adolescencia, consumo de alcohol por el compañero, paro, baja escolaridad y dependencia económica, los que repercutieron en la salud, con riesgos al embarazo. Conclusión: La violencia perpetrada por compañero íntimo fue el principal elemento externo que influenció el ambiente interno, con repercusiones a la salud. La Teoría representa una herramienta en la asistencia de enfermería que favorecerá la detección de los casos y el enfrentamiento de la violencia.

\section{DESCRIPTORES}

Violencia contra la Mujer; Embarazo; Maltrato Conyugal; Enfermería Maternoinfantil; Salud de la Mujer. 


\section{REFERENCES}

1. United Nations; Department of Economic and Social Affairs. The World's Women 2010: trends and statistics [Internet]. New York: ONU; 2010. [cited 2012 June 20]. Available from: http://unstats.un.org/unsd/demographic/products/Worldswomen/WW_full\%20report_color.pdf

2. Organização Pan-Americana da Saúde; Organização Mundial da Saúde. Prevenção da violência sexual e da violência pelo parceiro íntimo contra a mulher: ação e produção de evidência [Internet]. Genebra: OPAS/OMS; 2012 [citado 2012 jun. 22]. Disponível em: http://apps. who.int/iris/bitstream/10665/44350/3/9789275716359_por.pdf

3. Brasil. Lei n. 11.340, de 7 de agosto de 2006. Dispõe sobre a criação de mecanismos para coibir a violência doméstica e familiar contra a mulher e sobre a criação dos Juizados de Violência Doméstica e Familiar contra a Mulher, nos termos do $\S 8^{\circ}$ do Art. 226 da Constituição Federal [Internet]. Brasília; 2006 [citado 2011 ago. 25]. Disponível em: https://www.planalto.gov.br/ccivil_03/_Ato2004-2006/2006/Lei/ L11340.htm

4. Alhusen JL, Ray E, Sharps P, Bullock L. Intimate partner violence during pregnancy: maternal and neonatal outcomes. J Womens Health (Larchmt) [Internet]. 2015 [cited 2015 Apr 10];24(1):100-6. Available from: http://online.liebertpub.com/doi/abs/10.1089/jwh.2014.4872

5. Han A, Stewart DE. Maternal and fetal outcomes of intimate partner violence associated with pregnancy in the Latin American and Caribbean region. Int J Gynaecol Obstet [Internet]. 2014 [cited 2014 Apr 08];24(1):6-11. Available from: http://www.ijgo.org/article/ S0020-7292(13)00506-7/pdf

6. Velasco C, Luna JD, Martin A, Caño A, Martin-de-las-Heras S. Intimate partner violence against Spanish pregnant women: application of two screening instruments to assess prevalence and associated factors. Acta Obstet Gynecol Scand. 2014; 93(10):1050-8.

7. Makayoto LA, Omolo J, Kamweya AM, Harder VS, Mutai J. Prevalence and associated factors of intimate partner violence among pregnant women attending Kisumu District Hospital, Kenya. Matern Child Health J [Internet]. 2013 [cited 2014 July 03];17(3):441-7. Available from: http://www.ncbi.nlm.nih.gov/pmc/articles/PMC3574621/

8. Viellas EF, Gama SGN, Carvalho ML, Pinto LW. Fatores associados à agressão física em gestantes e os desfechos negativos no recémnascido. J Pediatr (Rio de Janeiro) [Internet]. 2013 [citado 2015 jun. 14];89(1):83-90. Disponível em: http://www.scielo.br/pdf/jped/v89n1/ v89n1a13.pdf

9. Azevêdo ACC, Araújo TVB, Valongueiro S, Ludemir AB. Intimate partner violence and unintended pregnancy: prevalence and associated factors. Cad Saúde Pública [Internet]. 2013 [cited 2015 June 14];29(12):2394-404. Available from: http://www.scielosp.org/pdf/csp/v29n12/ v29n12a05.pdf

10. Silva EP, Ludermir AB, Araújo TVB, Valongueiro SA. Frequency and pattern of intimate partner violence before, during and after pregnancy. Rev Saúde Pública [Internet]. 2011 [cited 2012 Oct 30];45(6):1044-53. Available from: http://www.scielo.br/pdf/rsp/v45n6/en_2806.pdf

11. Marcacine KO, Abuchaim ESV, Abrahão AR, Michelone CSL, Abrão ACFV. Prevalence of intimate partner violence reported by puerperal women. Acta Paul Enferm [Internet]. 2013 [cited 2014 July 03];26(4):395-400. Available from: http://www.scielo.br/pdf/ape/v26n4/en_ v26n4a15.pdf

12. Rosa LW, Falcke D. Violência conjugal: compreendendo o fenômeno. Rev SPAGESP [Internet]. 2014 [citado 2015 abr. 16];15(1):17-32. Disponível em: http://pepsic.bvsalud.org/pdf/rspagesp/v15n1/v15n1a03.pdf

13. Puccia MIR, Mamede MV. Revisão integrativa sobre a violência por parceiro íntimo na gestação. Rev Eletr Enferm [Internet]. 2012 [citado 2012 jul. 15];14(4):944-56. Disponível em: http://www.fen.ufg.br/revista/v14/n4/v14n4a24.htm

14. Rodrigues DP, Gomes-Sponholz FA, Stefanelo J, Nakano AMS, Monteiro JCS. Intimate partner violence against pregnant women: study about the repercussions on the obstetric and neonatal results. Rev Esc Enferm USP [Internet]. 2014 [cited 2014 Aug 10];48(2):206-13. Available from: http://www.scielo.br/pdf/reeusp/v48n2/0080-6234-reeusp-48-02-206.pdf

15. Levine MS. The conservation principles of nursing: twenty years later. In: Riehl-Sisca JP. Conceptual models for nursing practice. $3^{\text {rd }}$ ed. New York: Appleton e Lange; 1989. p. 325-37.

16. Bardin L. Análise de conteúdo. Lisboa: Edições 70; 2010.

17. Griebler CN, Borges JL. Violência contra a mulher: perfil dos envolvidos em boletins de ocorrência da Lei Maria da Penha. Psico [Internet]. 2013 [citado 2015 fev. 10]; 44(2):215-25. Disponível em: http://revistaseletronicas.pucrs.br/ojs/index.php/revistapsico/article/ viewFile/11463/9640

18. Barrios YV, Gelaye B, Zhong Q, Nicolaidis C, Rondon MB, Garcia PJ, et al. Association of childhood physical and sexual abuse with intimate partner violence, poor general health and depressive symptoms among pregnant women. PLoS One [Internet]. 2015 [cited 2015 Apr 14];10(1):e0116609. Available from: http://www.ncbi.nlm.nih.gov/pmc/articles/PMC4312043/

19. Azevêdo ACC, Araújo TVB, Valongueiro S, Ludermir AB. Intimate partner violence and unintended pregnancy: prevalence and associated factors. Cad Saúde Pública [Internet]. 2013 [cited 2015 Feb 20];29(12):2394-404. Available from: http://www.scielo.br/pdf/csp/v29n12/ v29n12a05.pdf

20. Apostólico MR, Hino P, Egry EY. Possibilities for addressing child abuse in systematized nursing consultations. Rev Esc Enferm USP [Internet]. 2013 [cited 2014 June 20];47(2):320-7. Available from: http://www.scielo.br/pdf/reeusp/v47n2/en_07.pdf

21. Abramsky T, Charlotte HW, Garcia-Moreno C, Devries K, Kiss L, Ellsberg M, et al. What factors are associated with recent intimate partner violence? Findings from the WHO multi-country study on women's health and domestic violence. BMC Public Health [Internet]. 2011 [cited 2013 July 10];11:109. Available from: http://www.ncbi.nlm.nih.gov/pmc/articles/PMC3049145/

22. Diniz NMF, Gesteira SMA, Lopes RLM, Mota RS, Pérez BAG, Gomes NP. Aborto provocado e violência doméstica entre mulheres atendidas em uma maternidade pública de Salvador-BA. Rev Bras Enferm [Internet]. 2011 [citado 2012 nov. 20]; 64(6):1010-15. Disponível em: http://www.scielo.br/pdf/reben/v64n6/v64n6a04.pdf

23. Pallitto CC, García-Moreno C, Jansen HA, Heise L, Ellsberg M, Watts C. Intimate partner violence, abortion, and unintended pregnancy: results from the WHO Multi-country Study on Women's Health and Domestic Violence. Int J Gynaecol Obstet. 2013;120(1):3-9. 